\title{
Identification of Ecological Risk Zoning on Qinghai-Tibet Plateau from the Perspective of Ecosystem Service Supply and Demand
}

\author{
Wei Shi $^{1}\left(\mathbb{D}\right.$, Fuwei Qiao ${ }^{2, *(\mathbb{D})}$ and Liang Zhou ${ }^{3}$ \\ 1 College of Geographic and Environmental Science, Northwest Normal University, Lanzhou 730070, China; \\ shiwei0716@163.com \\ 2 College of Economics, Northwest Normal University, Lanzhou 730070, China \\ 3 Faculty of Geomatics, Lanzhou Jiaotong University, Lanzhou 730070, China; zhougeo@126.com \\ * Correspondence: qfw279@nwnu.edu.cn
}

Citation: Shi, W.; Qiao, F.; Zhou, L. Identification of Ecological Risk Zoning on Qinghai-Tibet Plateau from the Perspective of Ecosystem Service Supply and Demand. Sustainability 2021, 13, 5366. https:/ / doi.org/10.3390/su13105366

Academic Editors: Vinod Kumar and Raj Setia

Received: 13 April 2021

Accepted: 7 May 2021

Published: 11 May 2021

Publisher's Note: MDPI stays neutral with regard to jurisdictional claims in published maps and institutional affiliations.

Copyright: (c) 2021 by the authors. Licensee MDPI, Basel, Switzerland. This article is an open access article distributed under the terms and conditions of the Creative Commons Attribution (CC BY) license (https:// creativecommons.org/licenses/by/ $4.0 /)$.

\begin{abstract}
With the interaction of global change and human activities, the contradistinction between supply and demand of ecosystem services in the Qinghai-Tibet Plateau is becoming increasingly tense, which will have a profound impact on the ecological security of China and even Asia. Based on land cover data on the Qinghai-Tibet Plateau in 1990, 2005, and 2015, this paper estimated the supply capacity of ecosystem services using the value equivalent method, calculated the demand for ecosystem services using population density and economic density, established an ecosystem risk index based on the idea of an ecosystem service matrix to reveal the spatio-temporal pattern of the supply and demand of ecosystem services in the Qinghai-Tibet Plateau, and identified the potential ecological risk areas arising from the imbalance between supply and demand. The results showed that: (1) In terms of the spatio-temporal pattern of land use change, the desert area of the Qinghai-Tibet Plateau decreased the most with $26,238.9 \mathrm{~km}^{2}$, and other types of land use increased, of which construction land increased by $131.7 \%$; (2) In terms of the supply and demand of ecosystem services, the Qinghai-Tibet Plateau was mainly dominated by low-level surplus areas, accounting for $64.0 \%$, and the deficit in some areas has worsened significantly; and (3) In terms of division pattern of ecological risk areas, the Qinghai-Tibet Plateau presented characteristics of high risk in the east and low risk in the west. The high-risk area accounted for 1.1\%, mainly distributed in the Huangshui Valley and the "One River and Two Tributaries" (Yarlung Zangbo River, Lhasa River, Nianchu River). The research results can provide reference for ecosystem management and policy formulation of the Qinghai-Tibet Plateau and have important significance for realizing the coupling and coordinated development of human-land relationship in Qinghai-Tibet Plateau.
\end{abstract}

Keywords: ecosystem services; supply and demand relationship; ecological risk identification; spatial pattern; Qinghai-Tibet Plateau

\section{Introduction}

Various services provided by the ecosystem are an important material basis for the development of human society. Various benefits obtained by human beings from the ecosystem enhance their welfare, but unreasonable development with high intensity seriously affects the sustainable development of the ecosystem [1]. In recent years, global climate change has profoundly affected nature and the ecosystem, and the supply of ecosystem services has changed accordingly. For instance, climate change leads to sea level rise, which leads to wetland loss or changes to the composition of vegetation [2]; climate change has altered freshwater ecosystems on both the supply side and the demand side, which will cause more severe floods, droughts, and sea level rise, and will intensify the magnitude and frequency of extreme events such as heavy rainfalls [3]. Increasingly warm and dry conditions can cause reduction in forest productivity and an increase in tree mortality, 
which can affect the provision of forest ecosystem services [4]. In addition, with the increase in the total population across the globe and the rapid development of the social economy, the demand for ecosystem services such as food, water resources, and energy has been intensified [5]. The consumption of global ecosystem services has been in an unsustainable state and will continue to deteriorate in many cases [6]. The status of ecosystem services is affected not only by the supply of ecosystem services but also by human activities. In measuring the sustainable development goals of an ecosystem, the relationship between supply and demand in ecosystem services is inseparable [7]. As the main driving force of the social economy, human activities play a subjective initiating role in strengthening or weakening ecosystem services [8]. Therefore, quantitative assessment of supply and demand of ecosystem services should be carried out to effectively identify high-risk areas of supply and demand in ecosystem services, so as to provide a basis for formulating sound management policies of ecosystem services, realizing the harmonious development of human and nature.

The Qinghai-Tibet Plateau is a relatively independent geographical unit with an average altitude of over $4000 \mathrm{~m}$. The plateau has a very fragile ecosystem, which is also the reason why it is one of the most sensitive regions to climate change in the world. It is also attracting more and more attention due to its unprecedented changes in ecological conditions [9]. In recent years, the plateau has been influenced by natural conditions and human activities. Especially in the last half-century, the urbanization level around the regions of the plateau has witnessed a rapid increase; human activities have intensified, and the land cover of the Qinghai-Tibet Plateau has changed dramatically, all of these factors leading to increasingly prominent problems [10]. The land cover changes such as the melting of permafrost and degenerating of grassland have seriously affected the supply capacity of ecosystem service of the Qinghai-Tibet Plateau. Moreover, intensified human activities have further increased the consumption of the ecosystem, accounting for more prominent contradistinctions between supply and demand. The melting of glacier permafrost of the plateau not only impacts the neighboring regions' sustainable development goals but also threatens the safety of billions of people [11]. The contradistinction between the rapidly increasing demand for ecosystem service and the limited supply of ecosystem service on the Qinghai-Tibet Plateau has seriously affected the Sustainable Development Goals (SDGs) of the region. Therefore, from the aspect of supply and demand balance of ecosystem service, this paper identifies the ecological risk of the Qinghai-Tibet Plateau to find out the spatial distribution characteristics between the service supply capacity of the Qinghai-Tibet Plateau ecosystem and the increasing social demand. It helps to explore promotion and restrictions imposed by the service of the plateau ecosystem on its economic development. The paper is also significant in its grasp of the ecological security pattern of the QinghaiTibet Plateau and its realization of regional sustainable development, providing theoretical support for ecosystem service payment and ecological compensation.

The remainder of this paper is organized as follows. Section 2 provides a review of previous studies. Section 3 presents an overview of the study area, the methodological approaches, and data utilized in this paper. Section 4 is the main part of this paper, including the characteristics of land use change, the spatial characteristics of supply and demand of ecosystem services, and the identification of ecological risk areas in the QinghaiTibet Plateau. Discussions and conclusions are drawn in Sections 5 and 6, respectively.

\section{Literature Review}

Since Costanza [12] conducted a value evaluation of global ecosystem service in 1997, the value of ecosystem service has been widely studied in the world. The Millennium Ecosystem Assessment (MEA) has pushed the study of the value of ecosystem service to a new height [13]. In the early stage, the research on ecosystem services mainly focused on the meaning, classification, and evaluation methods of ecosystem services. In terms of study content, domestic and foreign scholars have taken human needs into the assessment of ecosystem service in their studies. They believe that the status of ecosystem service is 
determined by both supply and demand [14]. Additionally, it has become a consensus that the spatial heterogeneity of ecosystem service is influenced by both supply and demand. Costanza [15] believes that the ecosystem that provides services is "natural capital" and puts forward a method for comprehensive evaluation of the three sub-objectives of effective allocation, fair distribution, and sustainable scale. In addition, the study of the relationship of supply and demand for ecosystem service mainly focuses on the evaluation of supply and demand [16-18], culture service [19], water regulating services [20], the relationship between supply and demand of soil conservation service [21], the weight of supply and demand of ecosystem service [22,23], spatial coupling of supply and demand [24,25], the influence of land-use change on supply and demand of ecosystem value [26,27], and so on. Some scholars combine the supply and demand of ecosystem service with the study of policy [28]. In the study scale, researchers estimate different types of ecosystem service mainly from the world, nation, basin, and other regional scales. For example, Costanza [12] assessed the value of the world's ecosystem service and natural capital; Tariq [29] explored the change of ecosystem service value in Pakistan; Miguel [30] studied the ecosystem service of the Baltic Sea through surveying and mapping. In the study method, the supply of ecosystem service is mostly estimated by the value equivalent method or Invest model. For example, Fan [31] and Srichaichana [32] estimate the supply of ecosystem service in Hangzhou, China, and Klong u-Tapao basin of Songkhla, Thailand, respectively, by using the Invest model. The concept of ecosystem needs varies from person to person based on how scholars think about it. Chaplin-Kramer et al. [33] developed a global ecosystem service model. Burkhard et al. [18] linked land use, ecosystem service supply, and demand; constructed a matrix of eco-system service supply and demand; and drew maps of the ecosystem service supply, demand, and budget in central Germany and subsequently elaborated the quantitative methods and spatial visualization concepts of supply and demand of ecosystem services in detail. Wang et al. [34] determined the matching model of ecosystem services through an ecosystem service provision index and land development index and revealed the spatial imbalance and spatial-temporal pattern changes of China's ecosystem service supply and demand. Peng [35] calculated the ecosystem service supply volume using the modified ecosystem service value volume, and calculated the degree of land use and development, population density, and land per capita GDP in the socioeconomic indicators of the ecosystem service demand selection. Based on the perspective of supply and demand, a zoning plan for the construction of an ecological network of green space in Guangdong Province, China, was proposed.

The Qinghai-Tibet Plateau is the highest plateau in the world, with an average altitude of more than $4000 \mathrm{~m}$. In addition, due to the dry and thin air, strong solar radiation, and low temperature, the Qinghai-Tibet Plateau has a harsh climate and is very desolate, which is not suitable for large-scale human habitation, much like the North and South Poles. Therefore, the Qinghai-Tibet Plateau is known as the Third Pole of the world. The assessment of its ecosystem service not only promotes the survival and development of human beings on the Qinghai-Tibet Plateau but also affects the global ecosystem service. The spatial difference of natural geography background in the Qinghai-Tibet Plateau is obvious, and the spatial distribution of population in this region is extremely unbalanced, which leads to the distribution of supply and demand of ecosystem service in the region and stronger difference of the ecological risks generated by the mismatch of the supply and demand. Xie et al. [36], based on some of the results of Costanza (1997) on global ecosystem service value assessment and the results of an ecological questionnaire survey conducted by Chinese professionals, established the land ecosystem service value per unit area table of China. The ecosystem service values of forest, grassland, farmland, marsh, lake, and desert were CNY 134.7, 35.1, 43.4, 554.9, 406.8, and $3.7 / \mathrm{km}^{2}$ per year, respectively. Lu et al. [37] evaluated the diversity of the Qinghai-Tibet Plateau ecosystem and estimated the economic value of the six ecological types of forests, grasslands, swamps, farmlands, and deserts, such as carbon sequestration and water conservation, and pointed out the importance of studying the ecosystem service of the Qinghai-Tibet Plateau. Wei et al. [38] studied land- 
use change on the Qinghai-Tibet Plateau and evaluated the change of ecosystem service value in the past 25 years - the results show that the total value of ecosystem services including supply, regulation, habitat, and cultural services has been increasing from 1995 to 2015. However, currently, there are few studies on the demand for ecosystem service or on the relationship between supply and demand in the Qinghai-Tibet Plateau, and even fewer studies on the identification of ecological risk areas. Moreover, the ecological status of the plateau can be better understood by assessing ecosystem service and identifying ecological risk from supply and demand of ecosystem service status.

In conclusion, from the aspect of research content, the research of a large quantity of literature about ecosystem research is more likely to focus on reflecting the service supply of regional natural background or embodying the weighted and collaborative relationship among ecosystem service functions. Although many scholars have listed the supply and demand of ecosystem services in the ecosystem services assessment, the research from the perspective of space based on supply and demand imbalance for identifying regional ecological risk is rather rare. From the research region, the research on supply and demand balance mainly focuses on the world, nation, and watershed, while little focuses on the Qinghai-Tibet Plateau-the third polar region of the world. Therefore, the innovative aspects of the paper lie in the following aspects. (1) From the perspective of research, the paper includes both the supply and demand of ecosystem service in the research of risk area identification and explores a method of identifying ecological risks based on the contradistinction between supply and demand. (2) The research area of the paper is of high regional research value. As the "Roof of the World" and "Third Pole of the World", the Qinghai-Tibet Plateau has an extremely fragile ecological environment. Additionally, with the continuous improvement of urbanization and surge of people's demand for ecosystem service, the Qinghai-Tibet Plateau has become a typical region where the contradistinction between humans and land is prominent.

\section{Research Areas, Methods, and Data Sources}

\subsection{Research Area}

The Qinghai-Tibet Plateau has a vast territory of about 2.5 million $\mathrm{km}^{2}$, accounting for one-fourth of China's total land area. With an average elevation of over $4000 \mathrm{~m}$, the internal natural environment of the plateau is distinct, and it is also the birthplace of many rivers. In the plateau, the temperature is low and the climate is cold. The northwest of the Qinghai-Tibet Plateau is dominated by a large area of desert steppe, while in the east of Tibet, the southeast of Qinghai Province is relatively humid. Forest belts are only distributed in the southern Nyingchi. Restricted by the natural conditions, the QinghaiTibet Plateau is sparsely populated and has an extremely uneven population distribution, with an average of fewer than four people per square kilometer, which is equivalent to one twenty-fifth of the national average population density. The regional combination of temperature and water conditions in the Qinghai-Tibet Plateau shows a gradual trend from warm and humid in the southeast to cold and arid in the northwest, showing a zonal alternate change of mountain, forest-alpine, meadow-alpine, steppe-alpine, and desert, with obvious horizontal zonal differentiation characteristics. According to the classification of physical regionalization of the Qinghai-Tibet Plateau by Zheng Du et al. [39], there are altogether 11 regions (Table 1, Figure 1) in the paper. 
Table 1. Physical regionalization of Qinghai-Tibet Plateau.

\begin{tabular}{cc}
\hline Physical Regionalization & Abbreviation \\
The alpine shrub and meadow areas of the Guoluo and Nagqu Plateau & AMGNP \\
The meadow grassland in the wide valley of the southern plateau of Qinghai & WGSPQ \\
The alpine steppe area in the Lake Basin of Qiangtang Plateau & ASLPQ \\
The alpine desert area of the Kunlun Alpine Plateau & ADKAP \\
The coniferous forest area of Alpine Canyon in Western Sichuan & CFACWS \\
CFQAQ & SSA \\
The shrub steppe area in the high valleys of southern Tibet & DQB \\
The Desert area in Qaidam Basin & MDAKM \\
The mountain desert area in the north wing of Kunlun Mountain & MDAN \\
The mountain desert area in Ngari & SBFST
\end{tabular}

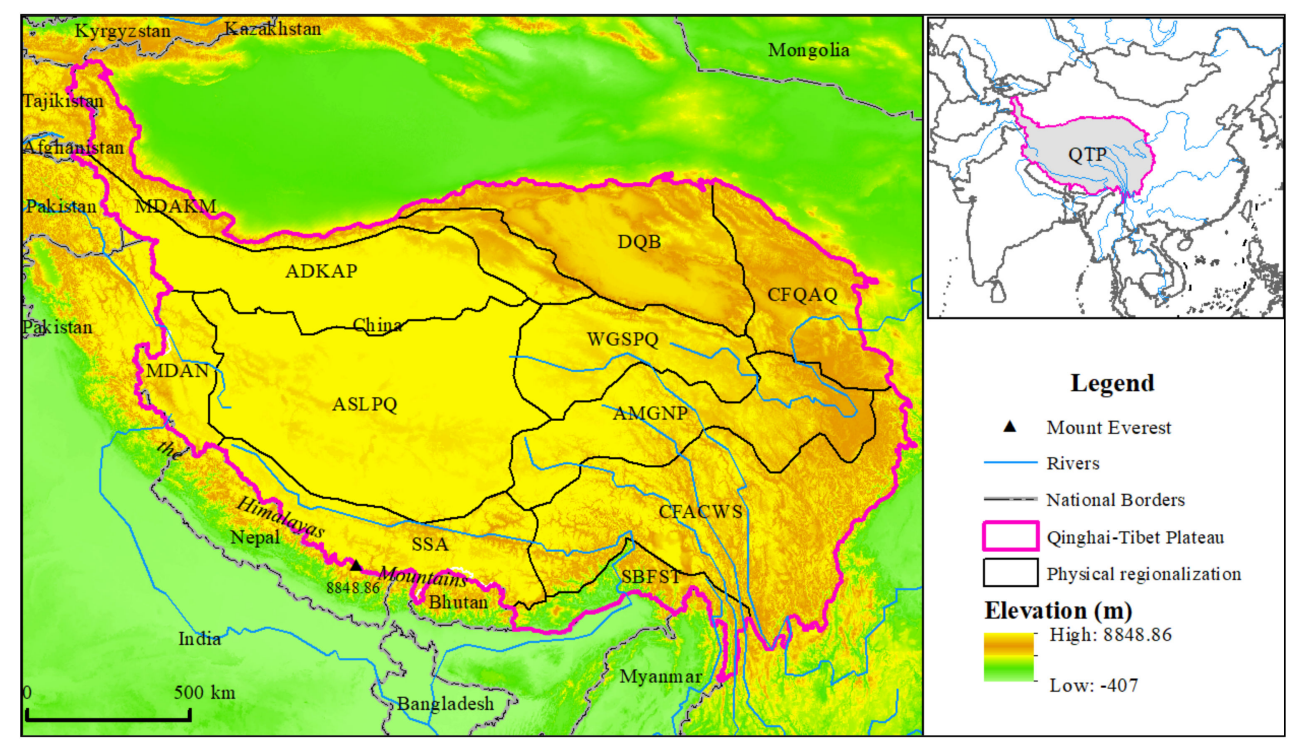

Figure 1. Overview of the study area.

Specifically, AMGNP is a semi-humid climate type in the sub-cold zone of the plateau, with cold and humid climate; the mean temperature in the warmest month is $6 \sim 10^{\circ} \mathrm{C}$, and the annual precipitation is $400 \sim 700 \mathrm{~mm}$, so it is a region with more precipitation on the plateau. There are the Tanggula Mountains and Bayan Har Mountains with an altitude of $5000 \sim 6000 \mathrm{~m}$, where the vegetation type is mainly alpine meadow. WGSPQ is a semi-arid area in the sub-cold zone of the plateau, with a cold climate. The average temperature in the warmest month is about $6 \sim 10^{\circ} \mathrm{C}$, and the annual precipitation can reach $200 \sim 400 \mathrm{~mm}$. Permafrost is distributed continuously here, which is neither natural forest growth nor suitable for crop planting. The vegetation type is mainly alpine grassland. ASLPQ is a semi-arid area in the sub-cold zone of the plateau, with cold climate and large annual changes in temperature. The average temperature in the warmest month is $6 \sim 10^{\circ} \mathrm{C}$, and the average temperature in the coldest month is below $-10^{\circ} \mathrm{C}$. The annual precipitation is about $100 \sim 300 \mathrm{~mm}$, the vegetation type is mainly alpine grassland, and there is a large no-man's land. ADKAP is an arid area in the sub-cold zone of the plateau, with harsh, cold, and arid climate, a warmest average monthly temperature of $3 \sim 7^{\circ} \mathrm{C}$, and a daily minimum temperature during the warm season that is mostly below $0{ }^{\circ} \mathrm{C}$. The annual precipitation is generally less than $100 \mathrm{~mm}$, and most precipitation is in the form of snow and hail. The area is rich in glacier resources. The main vegetation type is alpine desert vegetation. It is the highest part of the northwest of Qinghai-Tibet Plateau. CFACWS belongs to the humid and semi-humid area of the plateau's temperate zone, with a humid and semi-humid climate. It is a natural area dominated by high mountains and valleys. In valleys with an altitude 
of $2500 \sim 4000 \mathrm{~m}$, the warmest monthly average temperature is $12 \sim 18{ }^{\circ} \mathrm{C}$; on plateaus and mountains with an altitude of $4000 \sim 4500 \mathrm{~m}$, the annual precipitation is between $6 \sim 10^{\circ} \mathrm{C}$. The annual precipitation is $500 \sim 1000 \mathrm{~mm}$. It is the world's alpine plant region, with the richest flora, containing various types of mountain forests and alpine shrub meadow vegetation. CFACWS belongs to the humid and semi-humid area of plateau temperate zone, with humid and semi-humid climate. It is a physical region dominated by high mountains and valleys. In valleys with an altitude of $2500 \sim 4000 \mathrm{~m}$, the warmest monthly average temperature is $12 \sim 18{ }^{\circ} \mathrm{C}$; on plateaus and mountains at an altitude of $4000 \sim 4500 \mathrm{~m}$, the annual precipitation is between $6 \sim 10{ }^{\circ} \mathrm{C}$. The annual precipitation is $500 \sim 1000 \mathrm{~mm}$. The area is the most abundant alpine plant area in the world, distributed with various types of mountain forests and alpine shrub meadow vegetation. CFQAQ is a semi-arid plateau temperate zone with low altitude and mild climate. The average temperature in the warmest month is about $12 \sim 18{ }^{\circ} \mathrm{C}$, and that in the coldest month is $-5 \sim-12{ }^{\circ} \mathrm{C}$. The annual precipitation is $300 \sim 600 \mathrm{~mm}$, and the vegetation is mainly mountainous grassland. It is an important agricultural production base in Qinghai Province. CFQAQ is a temperate semi-arid area on the plateau with low altitude and mild climate. The average temperature of the warmest month is about $12 \sim 18{ }^{\circ} \mathrm{C}$, and the coldest month is about $-5 \sim-12{ }^{\circ} \mathrm{C}$. The annual precipitation reaches $300 \sim 600 \mathrm{~mm}$, and the vegetation is mainly mountain grassland. It is an important agricultural production base in Qinghai Province. SSA is a plateau temperate semi-arid area, including the main Himalayan mountains and their northern plateau lake basins and the upper and middle valleys of the Yarlung Zangbo River. There are many peaks above 8000 m, including Mount Everest, Makalu, Cho Oyu, and Shishapangma. The average temperature of the warmest month in the Kuangu Basin is $10 \sim 16{ }^{\circ} \mathrm{C}$, the average temperature of the coldest month is $0 \sim-12{ }^{\circ} \mathrm{C}$, and the annual precipitation is $300 \sim 500 \mathrm{~mm}$. The vegetation types are mainly mountain shrub grassland and alpine grassland. It is the main habitat of the Tibetan people and the most important area where crops are concentrated in Tibet. DQB is a plateau temperate arid region with sunny and dry climate and scarce precipitation. The average temperature in the warmest month is $10 \sim 18{ }^{\circ} \mathrm{C}$, and the average temperature in the coldest month is $-10 \sim-16^{\circ} \mathrm{C}$. The annual precipitation decreases from east to west: $100 \sim 200 \mathrm{~mm}$ in the east and only $10 \mathrm{~mm}$ in the west. The vegetation is mainly desert meadow. It is the driest area on the Qinghai-Tibet Plateau. MDAKM is a temperate and arid area of the plateau, including the eastern edge of the Pamirs and the north flank of the Kunlun Mountains in the west and central. The average elevation of the peaks of the Kunlun Mountains is above $6000 \mathrm{~m}$, and the annual average temperature is $0 \sim 6{ }^{\circ} \mathrm{C}$. The annual precipitation is about $70 \sim 150 \mathrm{~mm}$, and most of the mountains are sparse desert vegetation. MDAN is a plateau temperate arid region with strong solar radiation and long sunshine hours. The average temperature in the warmest month is $10 \sim 14{ }^{\circ} \mathrm{C}$, and the average temperature in the coldest month is $-9 \sim-13^{\circ} \mathrm{C}$. The area is dry and rainy, and the annual precipitation decreases gradually from south to north: less than $200 \mathrm{~mm}$ in the south and 50 150 $\mathrm{mm}$ in the central and northern parts. Mountain desert steppe and desert vegetation are mainly distributed in most areas. SBFST is a humid monsoon climate in tropical mountains, with year-round warmth and abundant rainfall. The average temperature of the warmest month is above $22{ }^{\circ} \mathrm{C}$, and the average temperature of the coldest month is below $13{ }^{\circ} \mathrm{C}$. The annual precipitation is $2500 \mathrm{~mm}$, and it reaches $4495 \mathrm{~mm}$ in some areas. It is the place with the most rainfall in Tibet and one of the rainy regions in China. There are evergreen broad-leaved trees growing in this area, and the forest is lush and evergreen all the year round.

\subsection{Data Sources and Pretreatment}

The land use data, population data, and economic data in the paper are all from the latest grid data of Resource and Environment Science and Data Center (http:/ /www.resdc. $\mathrm{cn}$ /; accessed on 10 December 2020), which have been widely used in related fields of land use. Additionally, the accuracy of the grid data met the need of the research in this paper. Remote sensing data was applied to monitor the data of land use status on the 
Qinghai-Tibet Plateau in 1995, 2005, and 2015 with a spatial resolution of $100 \mathrm{~m}$. Based on the original data classification system, the data were combined and processed. According to the data, there are six types of land-use in the plateau: cultivated land, forest, grassland, watershed, construction land, and desert. According to the research result of Xie et al. [36], the ecosystem service value of permanent glaciers is consistent with that of the desert. Therefore, permanent glacier data were incorporated into desert. The population data and economic data on the Qinghai-Tibet Plateau were grid data in 1995, 2005, and 2015, with a spatial resolution of $1 \mathrm{~km}$. To match with the resolution of land use data, resampling population data and economic data was conducted to get a new spatial resolution of $100 \mathrm{~m}$.

\subsection{Research Methods}

\subsubsection{Calculation of Ecosystem Service Supply}

Based on the questionnaire survey to 200 ecologists in our country, Xie et al. [36] developed equivalence factor tables of ecosystem service value of our country. They also assumed a linear relationship with the intensity of ecological service function and biomass and used the ecological service value of the biomass factor to further revise the unit price of various ecosystem services of the Qinghai-Tibet Plateau. In this paper, the unit value of different types of ecosystem services on the Qinghai-Tibet Plateau is based on Xie's research results, and it is as shown in Table 2.

Table 2. Unit value of different ecosystem services on the Qinghai-Tibet Plateau.

\begin{tabular}{cccccc}
\hline Land-Use & Cultivated Land & Forest & Grassland & Water & Desert \\
\hline $\begin{array}{c}\text { Unit value } \\
\left(\mathrm{CNY} / \mathrm{km}^{2}\right)\end{array}$ & 554.9 & 134.6 & 35.1 & 406.8 & 3.7 \\
\hline
\end{tabular}

According to the ecosystem service value per unit area in different regions of the Qinghai-Tibet Plateau, the total value of grid ecosystem service was calculated and researched. The supply capacity of ecosystem service is reflected by the value of ecosystem service within the grid.

$$
E s==\sum_{i=1}^{n} T V_{i}
$$

In Equation (1), Es is the total ecosystem service value of the evaluation unit; $T V_{i}$ is the total value of ecosystem services per unit area of class $i$ land use; $n$ is the number of land-use types.

\subsubsection{Estimation of Ecosystem Service Demand}

Wang [34] and Peng [35], selected three social and economic indicators to express ecosystem service demand: degree of land use development, population density, and land per capita GDP. Among the three indicators, the degree of land use development-namely, the percentage of construction land area and total regional land area-reflects the intensity of human consumption of ecosystem service. The larger the proportion of construction land area, the greater the degree of land use development and the higher the human consumption of ecosystem service. Population density can embody the amount of demand for ecosystem service. The higher the population density, the greater the total demand for ecosystem service. GDP per land reflects the level of human demand for ecosystem service. The stronger the regional economic strength is, the more the ecosystem service will be obtained. A specific formula is as follows:

$$
E d=A_{i} \times \lg \left(P O P_{i}\right) \times \lg \left(G D P_{i}\right)
$$

In Equation (2), Ed is the index of ecosystem service demand; $\mathrm{Ai}$, POPi and GDPi respectively represent the proportion of developed land, population density, and land per capita gross product of grid i. The social and economic indicators were publicly released by Resource and Environment Science and Data Center (http:/ / www.resdc.cn/; accessed 
on 10 December 2020), which uses a multi-factor weight distribution method to interpolate GDP data with administrative districts as statistical units to grid units, thereby realizing the spatialization of GDP. This dataset reflects the detailed spatial distribution of GDP in China. This paper uses the zoning statistics tool in ArcGIS to divide the social and economic dataset and population dataset into each cell to obtain GDPi. Then, the same process was adopted to obtain POPi in each cell. A raster calculator in ArcGIS was used to calculate the demand for ecosystem services in each cell using Equation (2).

\subsubsection{Ecosystem Service Risk Index}

The innovation of the method in this paper was to draw on the idea of B's supply and demand matrix, constructing an ecological risk index suitable for studying the QinghaiTibet Plateau. Specifically, in the process of research, land use data and publicly released socio-economic datasets were used to identify ecological risk areas by studying the mismatches between the supply and demand of ecosystem services. The great potential of spatial visualization of maps was used to determine the specific location of ecological risks, thereby supporting the assessment of ecological sustainable development. Referring to Burkhard's [18] thought of building an evaluation matrix of supply and demand of ecosystem service, the supply and demand of ecosystem service in this paper was classified into six levels from level 0-5 in accordance with the natural fracture method. As the level increased, the supply and demand of ecosystem service also increased. At this time, overlay analysis should be conducted to obtain spatially matched characteristics of ecosystem service. When the supply of ecosystem service fails to meet people's needs, which means that ecological products and services consumed by people exceed the threshold value of supply from the natural ecosystem, the natural ecosystem service then is considered to be exposed to risk. The profit and loss status of ecosystem service can be reflected according to the difference between the supply and demand of ecosystem service in different grids. The calculation formula is as follow:

$$
E R I=E s^{\prime}-E d^{\prime}
$$

In Equation (3), ERI represents the degree of risk; Es' and Ed' represent the total supply and demand of ecosystem service in different regions of the Qinghai-Tibet Plateau divided by Natural Breaks (Jenks). The smaller the value of ERI is, the greater the ecological risk in the region; when the value of ERI is negative, the ecological service in the research area is in deficit, and the ecological risk is aggravated. According to different assumed conditions, different areas are divided into high-risk areas, low-risk areas, hidden-risk areas, and risk-free areas based on their ecological risks. The specific meaning is shown in Table 3.

Table 3. The different degrees of risk (ERI) and their differences.

\begin{tabular}{|c|c|c|c|}
\hline Type & Assumed Condition & Degree of Risk & Difference \\
\hline High-risk & ERI $<-3$ & High risk & The loss of regional ecological services is serious. \\
\hline Low-risk & $-3<$ ERI $<0$ & Low risk & The loss of regional ecological services is less. \\
\hline Hidden-risk & $\begin{array}{c}\text { ERI }>0 \text { and ERI keeps } \\
\text { decreasing }\end{array}$ & Safety & $\begin{array}{l}\text { Regional ecological service supply is currently } \\
\text { sufficient, but ecological demand continues to } \\
\text { increase, and risks may arise in the future. }\end{array}$ \\
\hline Risk-free & $\begin{array}{c}\text { ERI }>0 \text { and ERI keeps } \\
\text { increasing }\end{array}$ & Safety & $\begin{array}{l}\text { Regional ecological service supply is currently } \\
\text { sufficient, ecological demand has not increased, and } \\
\text { there will be basically no risks in the future. }\end{array}$ \\
\hline
\end{tabular}

\section{Results}

\subsection{Analysis of Land-Use Change}

From the statistical table of land use on the Qinghai-Tibet Plateau between 1995 and 2015 (Table 4), it can be seen that there are rather significant differences in land-use area 
and rate change of different types of land on the Qinghai-Tibet Plateau during 1995 and 2015. In terms of change area, the desert changes the most, decreasing by $26,238.9 \mathrm{~km}^{2}$; the cultivated land changes the least, increasing by $412.46 \mathrm{~km}^{2}$; and the grassland increases the most, increasing by $14,732.2 \mathrm{~km}^{2}$. In terms of change rate, the land for construction has the largest change with a growth rate of $131.7 \%$, and the grassland has the smallest change with a growth rate of $1.0 \%$. Among all types of land, only deserts show a negative growth trend. The rapid growth of construction land is related to rapid urbanization on the Qinghai-Tibet Plateau in recent years, especially the resource exploitation in the Qaidam Basin. Additionally, the reduction of deserts and increase of water area may be related to the melting of glaciers and permafrost. Global warming leads glacier and permafrost to melt, and grassland to increase.

Table 4. Land use change on the Qinghai-Tibet Plateau from1995 to 2015.

\begin{tabular}{|c|c|c|c|c|c|c|c|}
\hline $\begin{array}{c}\text { Physical } \\
\text { Regionalization }\end{array}$ & $\begin{array}{c}\text { The Surface Area } \\
\text { of the Region } \\
\left(\mathbf{k m}^{2}\right)\end{array}$ & $\begin{array}{c}\text { Cultivated } \\
\text { Land } \\
\left(\mathrm{km}^{2}\right)\end{array}$ & $\begin{array}{l}\text { Forest } \\
\left(\mathrm{km}^{2}\right)\end{array}$ & $\begin{array}{l}\text { Grassland } \\
\left(\mathbf{k m}^{2}\right)\end{array}$ & $\begin{array}{l}\text { Water } \\
\left(\mathrm{km}^{2}\right)\end{array}$ & $\begin{array}{l}\text { Building } \\
\left(\mathrm{km}^{2}\right)\end{array}$ & $\begin{array}{l}\text { Desert } \\
\left(\mathrm{km}^{2}\right)\end{array}$ \\
\hline ASLPQ & $514,859.8$ & 0.9 & 5.1 & -3213.3 & 927.4 & 1.5 & 2281.6 \\
\hline DQB & $252,813.6$ & 132.5 & -45.1 & 9305.3 & 1672.1 & 641.1 & $-11,705.2$ \\
\hline CFQAQ & $169,118.8$ & 308.7 & -244.7 & 9303.6 & 620.8 & 354.4 & $-10,342.2$ \\
\hline SBFST & $83,417.8$ & -8.1 & 2.7 & 37.0 & 1.7 & 6.2 & -39.2 \\
\hline CFACWS & $438,957.5$ & -84.7 & 1508.7 & -1331.3 & 212.1 & 168.8 & -475.3 \\
\hline WGSPQ & $177,708.3$ & 33.1 & 14.8 & 6610.0 & 1745.7 & 4.3 & -8406.0 \\
\hline ADKAP & $269,139.1$ & 0.0 & 0.0 & -330.7 & 567.2 & 0.0 & -240.9 \\
\hline MDAN & $83,500.2$ & 6.6 & 0.0 & -27.9 & 17.5 & 5.0 & -2.2 \\
\hline SSA & $185,495.5$ & -33.0 & 32.3 & -177.8 & 21.7 & 65.9 & 90.2 \\
\hline AMGNP & $255,516.6$ & 48.5 & 1864.6 & -5230.1 & 512.0 & 124.1 & 2683.0 \\
\hline MDAKM & $153,221.9$ & 8.0 & 6.7 & -212.5 & 279.3 & 1.2 & -82.8 \\
\hline
\end{tabular}

In terms of regions, grasslands in ASLPQ decreased the most with a total decrease of $3213.3 \mathrm{~km}^{2}$ within 20 years and an increase of $2281.6 \mathrm{~km}^{2}$ of desert area. DQB had the largest increase in the area of grasslands with an increase of $9305.3 \mathrm{~km}^{2}$ and the largest increase in construction area among the 11 natural areas. It is also the natural area with the largest decrease in the desert area. CFQAQ had the largest growth rate of construction land, the largest decrease in desert land of $10,342.2 \mathrm{~km}^{2}$, the largest decrease in humid broad-leaved forest desert area of $39.2 \mathrm{~km}^{2}$, and an increase in grassland area of $37.02 \mathrm{~km}^{2}$. CFACWS increased by $1508.66 \mathrm{~km}^{2}$, while its grassland area decreased by $1131.3 \mathrm{~km}^{2}$. SQR had a decrease in the desert area of $8406.0 \mathrm{~km}^{2}$, an increase in grassland area of $6610.0 \mathrm{~km}^{2}$, and an increase in watershed area of $1745.7 \mathrm{~km}^{2}$, which is the largest watershed increase among the 11 natural areas. In ADKAP, there was no change in woodland, none in construction land or cultivated land, a slight decrease in grassland and desert land, and an increase in the watershed of $567.2 \mathrm{~km}^{2}$. The change of various lands in MDAN was rather small, with a decrease in grassland and desert land, and the largest increase in the watershed area of $17.5 \mathrm{~km}^{2}$. The grassland area of south Tibet had a decrease in cultivated land and grassland; an increase in the watershed, construction area and desert; and the largest decrease in cultivated land of $33.0 \mathrm{~km}^{2}$. AMGNP had the largest increase in the desert of $2683 \mathrm{~km}^{2}$, a large decrease in the grassland of $5230.1 \mathrm{~km}^{2}$, and a large increase in forest land. MDAKM had the largest increase in the watershed of $279.3 \mathrm{~km}^{2}$ and a decrease in the grassland of $212.5 \mathrm{~km}^{2}$.

\subsection{Temporal and Spatial Characteristics of Ecosystem Service Supply on the Qinghai-Tibet Plateau}

According to statistical results (Figure 2), the relationship between supply and demand of ecosystem service on the Qinghai-Tibet Plateau was concentrated in the range of low deficit to low surplus, with a trend of constantly expanding in deficit areas and worsening of deficit in partial areas. Specifically, in 1995, the surplus area of the Qinghai-Tibet Plateau 
was $1734,000 \mathrm{~km}^{2}$, accounting for $64.0 \%$ of the total area, among which the fourth-level and fifth-level of surplus area of was $153,200 \mathrm{~km}^{2}$. The balance area exceeded one-fourth of the total area, with an area of $773,600 \mathrm{~km}^{2}$. At this time, the deficit area was relatively small, only accounting for $7.5 \%$ of the total area, with no appearance of the fourth-level and fifth-level deficit area. In 2005, the surplus area of the ecosystem in the QinghaiTibet Plateau decreased continuously, and a high-level deficit area began to appear. The surplus area in 2005 was 13.3\% smaller than that in 1995, which was mainly due to the decrease in the second-level surplus area. Because of the transformation of surplus area, balance area has been in an increasing trend in the past 10 years, with an increase of $6.1 \%$. The deficit area covers an area of $383,200 \mathrm{~km}^{2}$. The second-level deficit area had the largest increase rate of $127.1 \%$, while the fourth-level deficit area began to appear. In 2015, the surplus area and balance area further reduced, with the area respectively being $141,400 \mathrm{~km}^{2}$ and $806,000 \mathrm{~km}^{2}$. There were 1227 deficit areas, with the area being $490,800 \mathrm{~km}^{2}$, which increased by $32.1 \%$ compared with 2005 . The fourth-level deficit area increased by $2000 \mathrm{~km}^{2}$, and the first-level deficit area grew the fastest, with a growth rate arriving at $80.9 \%$. Overall, the deficit area continued to expand. In terms of regions, the second-level surplus area in the Qiangtang Plateau decreased the most significantly, with a decrease of nearly $175,200 \mathrm{~km}^{2}$. The decreased second-level surplus area mainly transformed to the first-level surplus area. In CFQAQ, high-level deficit area took a large proportion and the fourth-level deficit area increased from 0 to $4800 \mathrm{~km}^{2}$ within 20 years. As such, CFQAQ has become the area where high-level deficit area is distributed most on the Qinghai-Tibet Plateau. The ecological deficit of DQB, SSA, and CFACWS gradually expanded. The ecological surplus area of the subtropical broad-leaved forest region was $77,600 \mathrm{~km}^{2}$, accounting for more than $68 \%$ of the sub-region.



(a)

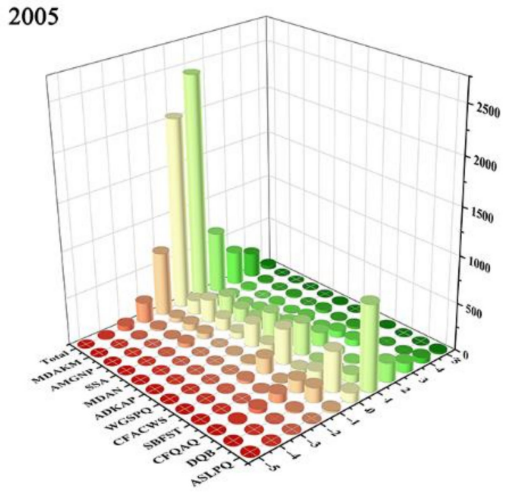

(b)

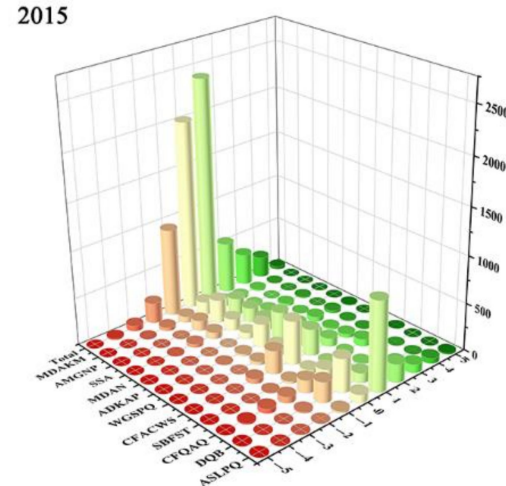

(c)

Figure 2. Statistical maps of risk levels in different natural areas on the Qinghai-Tibet Plateau from 1995 to 2015. (a) 1995, (b) 2005, (c) 2015 .

To further determine the spatial position of the supply and demand balance state, a spatial visualization was conducted (Figure 3). The spatial distribution chart of the balance of supply and demand over the Qinghai-Tibet Plateau shows that the overall pattern of the Qinghai-Tibet Plateau risk region remained unchanged during 1995 and 2015, while the contradistinction between local supply and demand intensified, presenting an obvious spatial differentiation pattern (Figure 3). Specifically, ASLPQ, CFQAQ, and MDAN maintained the second-level surplus in ecosystem service for a long time, while the humid broad-leaved forest region maintained fourth-level in ecosystem service for a long time. The proportion of deficit areas in CFQAQ and SSA was large, and the scope of deficit areas was expanding. The transition from a surplus area to a deficit area in ecosystem service was most significant in AMGNP, DQB, and WGSPQ, which was mainly determined by the vegetation type and spatial activities of humans on the Qinghai-Tibet Plateau. The main vegetation type in ASLPQ, WGSPQ, and MDAN was meadow vegetation with low ecosystem service supply capacity and high average altitude. The three regions are also famous 
uninhabited areas in the world with low demand for ecosystem service and long-term low surplus. The Huangshui Valley in CFQAQ and "One River and Two Tributaries" in SSA are the center of population, economy, and culture of the whole Qinghai-Tibet Plateau region, with intensive human activities. Therefore, the ecological deficit area of the two regions expanded sharply and the deficit level was high. DQB had the lowest vegetation coverage rate but is abundant in mineral variety. It is a relatively developed area within the plateau with more ecological demand but less ecological supply. With the opening of Chengwenqiong Expressway, Qiongming Expressway, Chengya Expressway, and another major Sichuan-Tibet Expressway in AMGNP and CFACWS, the communication between southeast Tibet and eastern Sichuan was strengthened; human activities were enhanced; the demand for ecosystem service increased; and the contradistinction between supply and demand gradually increased.


A

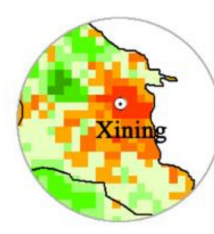

A

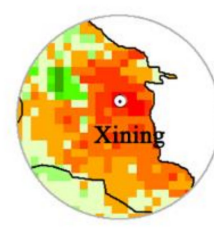

A

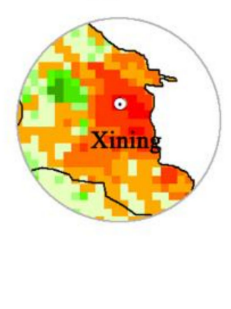

B

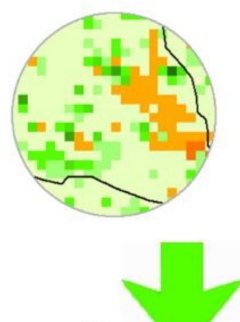

B
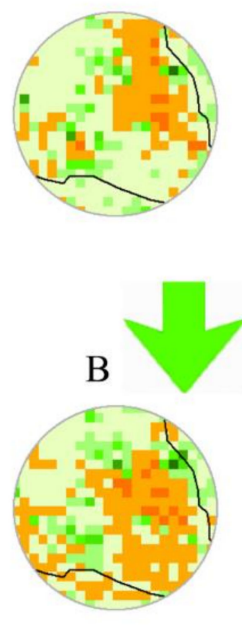

C

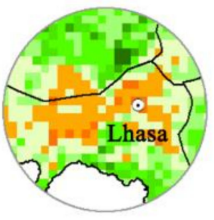

C

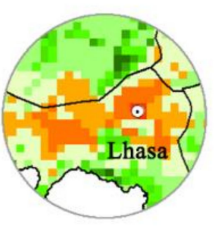

C

D

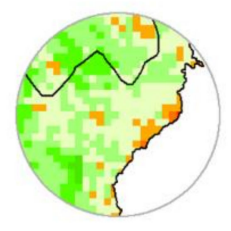

D

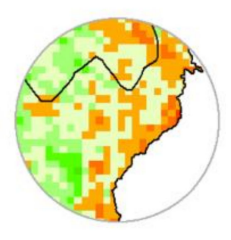

D
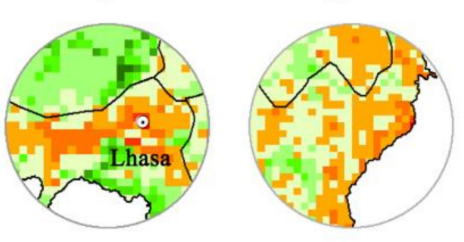

Figure 3. Statistical maps of risk levels in different natural areas on the Qinghai-Tibet Plateau from 1995 to 2015. (A-D are the typical areas with the most dramatic changes.)

\subsection{Spatial Distribution of Ecosystem Service Ecological Risk Area}

According to the ecosystem service risk index and its change, spatial distribution of the type of ecological risk area and the ecological risk status of different ecological areas on the Qinghai-Tibet Plateau were determined (Figure 4). The results show that the proportion of risk level in the Qinghai-Tibet Plateau varied greatly, with an overall trend of high proportion in the east and low proportion in the west. The dominant type was a risk-free area, with a total area of $1,915,200 \mathrm{~km}^{2}$, accounting for $70.7 \%$. In terms of regions, the high-risk area accounted for $13.2 \%$ of CFQAQ, which is the natural area with the highest proportion of the high-risk area. Furthermore, the low-risk area was $78,400 \mathrm{~km}^{2}$, accounting for $42.5 \%$ of CFQAQ. The low-risk area in DQB was $84,800 \mathrm{~km}^{2}$, accounting for $31.8 \%$ of the total area. The proportion of low-risk areas in SSA, AMGNP, CFACWS, and 
MDAKM was more than $20 \%$, with a high ecological risk in partial areas. The low risk of WGSPQ and SBFST was less than 10\%, with overall low ecological risk. MDAN, WGSPQ, and ADKAP had the lowest ecological risks. In the three natural areas, risk-free area respectively occupied $98.3 \%, 94.3 \%$, and $93.0 \%$ of the total area. The total risk-free area of the three natural areas was $837,200 \mathrm{~km}^{2}$, accounting for $30.9 \%$ of the Qinghai-Tibet Plateau.

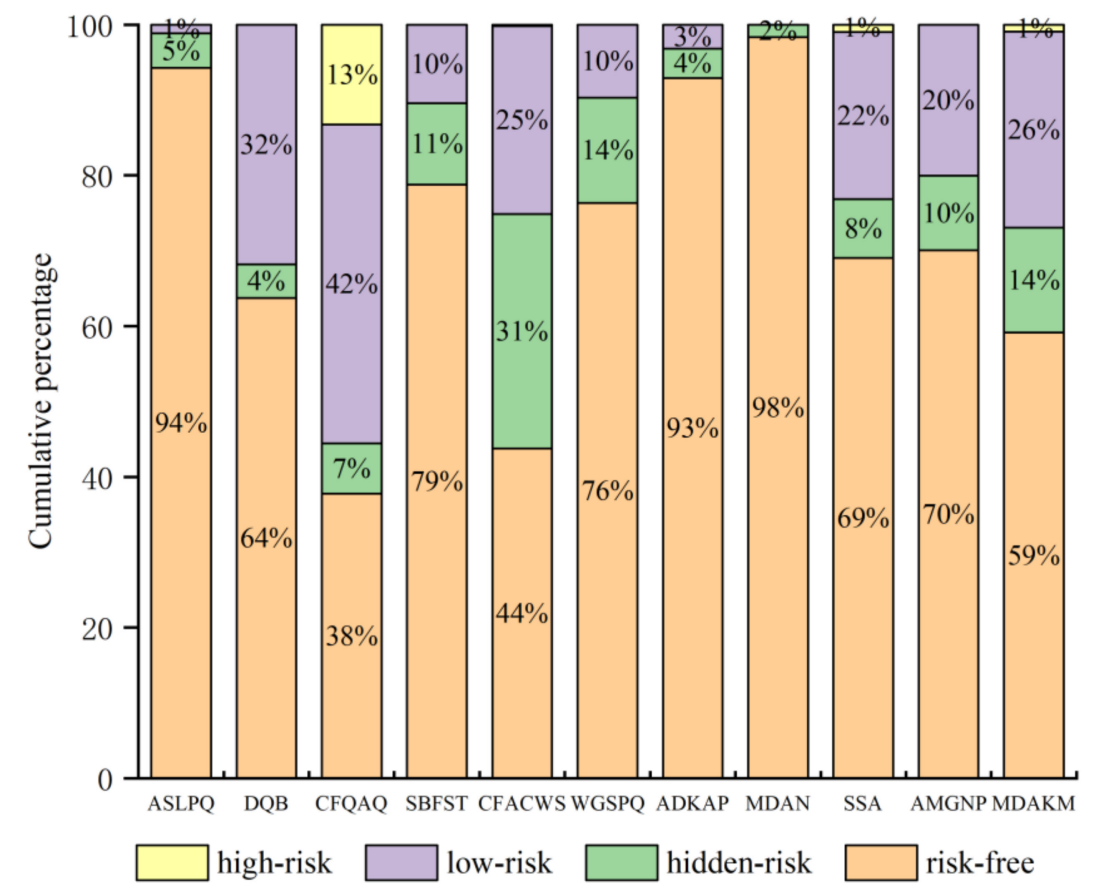

Figure 4. The proportion of different ecological risk levels in the Qinghai-Tibet Plateau.

In terms of spatial pattern, the ecological risk of the Qinghai-Tibet Plateau was high in the east, low in the west, and prominent in partial areas (Figure 5). The high-risk area was mainly distributed in CFQAQ and partially distributed in SSA and MDAKM. The low-risk area was mainly distributed in CFQAQ, DQB, AMGNP, and CFACWS. The riskfree area mainly was distributed in MDAN, ADKAP, ASLPQ, WGSPQ, SBFST, and the south area of SSA. CFACWS was the concentrated distribution area of the hidden-risk area, which is consistent with the range of human activities on the Qinghai-Tibet Plateau. The Huangshui Valley in CFQAQ and the "One River and Two Tributaries" in SSA are important population agglomeration areas on the Qinghai-Tibet Plateau. The demand of the two areas for ecosystem service is strong, and the ecological risk level caused by the imbalance between supply and demand is high. Most of the central and western regions of the plateau are alpine desert areas with sparse population distribution, less demand for local ecosystem service, and low ecological risk. CFACWS is located in the area of the Hengduan Mountains. Though there are more people in the valleys of Jinsha River, Nujiang River, and Lancang River within the coniferous forest area, the area has a high forest coverage rate, sufficient water supply, and adequate supply of ecosystem service. Although the human demand for ecological services is increasing in the area, it is still in surplus. 




Figure 5. Spatial distribution map of different ecological risk levels in the Qinghai-Tibet Plateau.

\section{Discussion}

\subsection{Establishment and Sectional Management of Warning System of the Qinghai-Tibet} Plateau Ecosystem

Based on the relationship between supply and demand of ecosystem service, the establishment of a scientific ecological risk warning system can accurately evaluate risk status and trend and is beneficial to guide and coordinate the contradistinction between ecological society development and ecological protection. The Qinghai-Tibet Plateau, as the Third Pole in the world, owns limited space for humans to live in, an extremely fragile ecological environment, and a huge spatial difference of the ecosystem service. Therefore, it is urgent to establish an early-warning system and conduct partition management to deal with the differentiation pattern of ecological risk. According to research results, the contradistinction between supply and demand of ecosystem service is the most prominent in CFQAQ, SSA, and DQB. The risk area of the three regions is relatively large and can be identified as serious warning areas. The ecological risks are more prominent in the Huangshui Valley in CFQAQ and the "One River and Two Tributaries" in SSA. These high ecological risk areas are agricultural regions of the Qinghai-Tibet Plateau, with highly concentrated population distribution and a rather large amount of construction land. The areas are places where the contradistinction between supply and demand of ecosystem service in the region is the most prominent and usually presents a model of medium supply and high demand. Additionally, because of the siphon effect and superiority of natural conditions, the population concentration of the region is expected to be in a long-term growth trend. The region will be the focus where the supply and demand of ecosystem service are imbalanced; thus, the region should be the focus of monitoring and regulation. It is also necessary to adopt corresponding policies to implement protection mechanisms of national spatial development in a bid to determine a reasonable ecological red line and to make rational allocations of life, production, and ecological space. DQB, AMGNP, and CFACWS can be identified as light warning areas where human activities are the most active besides CFQAQ and SSA on the Qinghai-Tibet Plateau. The characteristics shared by the two areas are low ecological risk levels but wide and dispersed distribution of ecological risk; thus, the following measures should be taken to protect the two regions: continuous enhancement of ecological restoration and construction, reasonable resources utilization, and effective control of human activities so as to enable them to accord with the requirements of bearing capacity of the local ecosystem. The eastern region of the coniferous forest region in the west of Sichuan is the main distribution area of the hidden-risk area 
and is identified as a warning region. Currently, the ecosystem service of CFACWS is safe. However, the scale of human activities in the Qinghai-Tibet Plateau is expanding from east to west. The human activities relying mainly on the river and valley of the Hengduan Mountains are increasing. It is necessary to formulate and strengthen corresponding risk control measures, to coordinate development and protection, and to ensure the normal supply capability of ecosystem service. ADKAP, MDAN, ASLPQ, and SSA are identified as unsafe areas, with the specific feature of basically being in a risk-free state. The four regions also have fragile ecological systems and a small supply of ecosystem service value. However, as the four regions have poor living conditions, low population bearing capacity, sparse distribution of population, and small ecosystem service demand, the four regions demonstrate a model of low supply and low demand and a low-level balance of ecosystem service supply. Moreover, once the demand for ecosystem services exceeds its supply capacity, the ecosystem of the four regions will be vulnerable to damage and will have a poor recovery ability. Therefore, the supervision of ecosystem service should be strengthened to prevent the negative feedback effect of ecosystem damage and to maintain the low-level balance of the plateau grassland region.

\subsection{Impact of Supply and Demand Estimation of Ecosystem Service on the Identification of Ecological Risk Area}

The estimation of supply and demand of ecosystem service is key to studying the framework of supply and demand of ecosystem service. In this paper, the spatial mismatch between the supply and demand of ecosystem service on the Qinghai-Tibet Plateau was evaluated and the ecosystem risk areas were identified by a mapping method with reference to the supply and demand matrix of ecosystem service proposed by Burkhard et al. However, some ecosystem services are of mobility, and the supply and demand of ecosystem service may be spatially inconsistent. Thus, simple spatial superposition cannot be used to measure spatial mobility of ecosystem service, which is also the limitation of the mapping method. According to the measurement result, the contradistinction between supply and demand of ecosystem service was most prominent in the "One River and Two Tributaries" and the Huangshui Valley. However, as the center of human development on the Qinghai-Tibet Plateau, the development of the two areas is supplemented by the whole Qinghai-Tibet Plateau.

The ecosystem service demand calculated with reference to the social and economic factors such as population and GDP can only be regarded as a relative amount for reference when calculating the ecosystem service supply relationship. If an absolute relationship between supply and demand as a way of determining the risk area of the ecological system can be sought, it would be more conducive were it to determine the ecological risk area from the perspective of ecosystem service of supply and demand. As the Qinghai-Tibet Plateau is an ecological barrier in Asia, the measurement of the spatial spillover effect of its ecological service on other regions should also be an important aspect of the research and will be further reflected in future research.

\subsection{The Impact of Global Warming on Water Resources of the Qinghai-Tibet Plateau}

Qinghai-Tibet Plateau is the birthplace of many major rivers in Asia, and it provides important ecosystem services to most parts of Asia in the form of fresh water. It is an important water tower for maintaining the ecosystem and socio-economic development in China, Southeast Asia, and South Asia [40]. Major rivers such as the Indus River, Ganges River, Yarlung Zangbo River, Nu River, Mekong River, Yangtze River, and Yellow River are mainly supplied by melting glaciers on the Qinghai-Tibet Plateau. With global warming, glaciers on the Qinghai-Tibet Plateau are retreating at the speed at which people enter the region. In the short term, the melting of glaciers will increase the flow of many rivers, which is beneficial to agricultural production in India, China, and Bangladesh and can alleviate the pressure of urban water use [41]. However, with the deepening of the melting degree of glaciers, the water resources supplied to rivers are becoming less and less, which may eventually lead river water resources to fail to meet the needs of human production 
and life, thus affecting the economic development of China, South Asia, Southeast Asia, and other regions, and even threatening the lives and safety of people in these regions. Therefore, for the Qinghai-Tibet Plateau, changes of freshwater resources are a real barrier to social and economic development in the context of global warming.

\section{Conclusions}

Based on the land-use change data of the Qinghai-Tibet Plateau and the ecosystem service supply matrix, the supply and demand of ecosystem service on the QinghaiTibet Plateau and their spatial matching were discussed in the paper, which is of great significance for the sub-region protection of the Qinghai-Tibet Plateau ecosystem. The conclusions drawn are as follows.

(1) The change of land-use types in different natural areas of the Qinghai-Tibet Plateau is quite different. The largest area of change was deserts, which decreased by $26,238.9 \mathrm{~km}^{2}$, while the smallest area of change was cultivated lands, which increased by $412.5 \mathrm{~km}^{2}$. The change rate of the construction land was the largest, with an increase rate of $131.7 \%$. Among different land types, the area of the cultivated land increased the most in CFQAQ, with an increase of $308.7 \mathrm{~km}^{2}$, and CFACWS decreased the most, with a decrease of $84.7 \mathrm{~km}^{2}$. The forest area increased the most in AMGNP, with an increase of $1864.6 \mathrm{~km}^{2}$, and decreased the most in CFQAQ. DQB and CFQAQ are the natural areas where grassland area increased the most, with an increase of $9305.3 \mathrm{~km}^{2}$ and $9303.6 \mathrm{~km}^{2}$, while the Guoluo grassland region decreased by $5230.12 \mathrm{~km}^{2}$. The watershed area of different natural areas increased and the watershed area of AMGNP increased the most, which was by $1745.7 \mathrm{~km}^{2}$. The construction land growth and growth rate were the largest in DQB, which were $641.06 \mathrm{~km}^{2}$ and $580.1 \%$. The desert area of DQB decreased the most, with a decrease of $11,705.2 \mathrm{~km}^{2}$, while the desert area of AMGNP increased by $2683.0 \mathrm{~km}^{2}$.

(2) The supply and demand of ecosystem service in the Qinghai-Tibet Plateau were dominated by low surplus areas, but deficit areas expanded from east to west, and the deficit in some areas increased. The Huangshui Valley in CFQAQ and in the "One River and Two Tributaries" in SSA had the highest ecological deficit with the fifth-level ecological deficit accounting for the highest deficit. The evergreen subtropical broad-leaved forest region had the highest level of surplus, and $60.28 \%$ of its area was a high-level surplus area. The alpine steppe region in ASLPQ, MDAN, and WGSPQ maintained a low surplus for a long time, accounting for more than $60 \%$ of surplus.

(3) The proportion of risk level in the Qinghai-Tibet Plateau varied greatly with a trend of high proportion in the east and a low proportion in the west. The dominant type was in risk-free areas, with a total area of $1,915,200 \mathrm{~km}^{2}$, accounting for $70.7 \%$ of the total area of the plateau. The high-risk area in CFQAQ was the largest, accounting for $87.5 \%$, which was mainly concentrated in the Huangshui Valley. The ecological risk was the lowest in ASLPQ, ADKAP, and MDAN. CFACWS was a highly concentrated distribution area of hidden-risk area, with its eastern region presenting a low-risk level. The "One River and Two Tributaries" in SSA was the place where a high-risk area was distributed, while the remaining areas were ecologically safe.

The paper constructs an ecological risk identification framework from the spatial mismatch between the supply and demand of ecosystem services, provides a new perspective for the identification of ecological risks, and conducts an empirical study on the ecological risks of the Qinghai-Tibet Plateau. The results are consistent with previous studies, which prove that the research in this article has a certain value and can provide a certain reference for the sustainable development of the Qinghai-Tibet Plateau. Generally speaking, the Qinghai-Tibet Plateau is moving toward the United Nations Sustainable Development Goals, land use is developing in a good direction, the degree of land desertification is decreasing, the ecosystem service supply capacity is continuously improving, and most areas of the ecosystem are still in a safe state. However, the demand for ecosystem services in some areas of the Qinghai-Tibet Plateau has increased drastically, and ecological risks are concentrated in areas where human activities have increased. Therefore, human activ- 
ities on the Qinghai-Tibet Plateau must be monitored and controlled, and the ecological sustainable development of the Qinghai-Tibet Plateau must be protected to the utmost extent because the ecological system of the Qinghai-Tibet Plateau is very fragile, and once it is destroyed, the likelihood of its reversibility is very small. It is worth noting that the Hehuang Valley and the "One River and Two Tributaries" are important protection areas for the ecological sustainable development of the entire Qinghai-Tibet Plateau. At the same time, these two regions are also densely populated areas and economic centers on the Qinghai-Tibet Plateau. Land urbanization has changed the types of land use and increased the demand for ecosystem services ([42], [43]), which is an important threat to the ecological environment. The urban land in Qinghai-Tibet Plateau has grown rapidly, and the area has increased by $96.9 \%$ [44], so handling the relationship between economic development and ecological protection in the region will be the key to maintaining the sustainable development of the Qinghai-Tibet Plateau ecosystem.

Author Contributions: W.S. wrote the paper; F.Q. conceived and designed the research; L.Z. provided some useful advice. All authors have read and agreed to the published version of the manuscript.

Funding: This research was funded by Strategic Priority Research Program of the Chinese Academy of Sciences (No. XDA20040401).

Institutional Review Board Statement: Not applicable.

Informed Consent Statement: Not applicable.

Data Availability Statement: Not applicable.

Acknowledgments: Thanks to the hard-working editors and valuable comments from reviewers.

Conflicts of Interest: The authors declare no conflict of interest.

\section{References}

1. Zhai, T.; Wang, J.; Fang, Y.; Huang, L.; Liu, J.; Zhao, C. Integrating Ecosystem Services Supply, Demand and Flow in Ecological Compensation: A Case Study of Carbon Sequestration Services. Sustainability 2021, 13, 1668. [CrossRef]

2. Hindsley, P.; Yoskowitz, D. Global change-Local values: Assessing tradeoffs for coastal ecosystem services in the face of sea level rise. Glob. Environ. Chang. 2020, 61, 102039. [CrossRef]

3. Pham, H.V.; Torresan, S.; Critto, A.; Marcomini, A. Alteration of freshwater ecosystem services under global change-A review focusing on the Po River basin (Italy) and the Red River basin (Vietnam). Sci. Total Environ. 2019, 652, 1347-1365. [CrossRef]

4. Morán-Ordóñez, A.; Ameztegui, A.; De Cáceres, M.; de-Miguel, S.; Lefèvre, F.; Brotons, L.; Coll, L. Future trade-offs and synergies among ecosystem services in Mediterranean forests under global change scenarios. Ecosyst. Serv. 2020, 45, 101174. [CrossRef]

5. Yuan, M.H.; Lo, S.L. Ecosystem services and sustainable development: Perspectives from the food-energy-water Nexus. Ecosyst. Serv. 2020, 46, 101217. [CrossRef]

6. Carpenter, S.R.; DeFries, R.; Dietz, T.; Mooney, H.A.; Polasky, S.; Reid, W.V.; Scholes, R.J. Millennium ecosystem assessment: Research needs. Science 2006, 314, 257-258. [CrossRef]

7. Syrbe, R.-U.; Walz, U. Spatial indicators for the assessment of ecosystem services: Providing, benefiting and connecting areas and landscape metrics. Ecol. Indic. 2012, 21, 80-88. [CrossRef]

8. Davids, R.; Rouget, M.; Burger, M.; Mahood, K.; Ditlhale, N.; Slotow, R. Civic Ecology Uplifts Low-Income Communities, Improves Ecosystem Services and Well-Being, and Strengthens Social Cohesion. Sustainability 2021, 13, 1300. [CrossRef]

9. Xia, M.; Jia, K.; Zhao, W.; Liu, S.; Wei, X.; Wang, B. Spatio-temporal changes of ecological vulnerability across the Qinghai-Tibetan Plateau. Ecol. Indic. 2021, 123, 107274. [CrossRef]

10. Cui, X.; Graf, H.-F. Recent land cover changes on the Tibetan Plateau: A review. Clim. Chang. 2009, 94, 47-61. [CrossRef]

11. Cyranoski, D. The long-range forecast. Nature 2005, 438, 275-276. [CrossRef]

12. Costanza, R.; d'Arge, R.; de Groot, R.; Farber, S.; Grasso, M.; Hannon, B.; Limburg, K.; Naeem, S.; O'neill, R.V.; Paruelo, J.; et al. The value of the world's ecosystem services and natural capital. Nature 1997, 387, 253-260. [CrossRef]

13. Vignoli, F.; de Luca, C.; Tondelli, S. A Spatial Ecosystem Services Assessment to Support Decision and Policy Making: The Case of the City of Bologna. Sustainability 2021, 13, 2787. [CrossRef]

14. Wang, Z.; Zhang, L.; LI, X.; Li, Y.; Wang, P.; YAN, J. Spatio-temporal pattern of supply-demand risk of ecosystem services at regional scale: A case study of water yield service in Shaanxi province. Acta Ecol. Sin. 2020, 40, 1887-1900. (In Chinese)

15. Costanza, R. Valuing natural capital and ecosystem services toward the goals of efficiency, fairness, and sustainability. Ecosyst. Serv. 2020, 43, 101096. [CrossRef]

16. Wolff, S.; Schulp, C.J.E.; Kastner, T.; Verburg, P.H. Quantifying spatial variation in ecosystem services demand: A global mapping approach. Ecol. Econ. 2017, 136, 14-29. [CrossRef] 
17. Mehring, M.; Ott, E.; Hummel, D. Ecosystem services supply and demand assessment: Why social-ecological dynamics matter. Ecosyst. Serv. 2018, 30, 124-125. [CrossRef]

18. Burkhard, B.; Kroll, F.; Nedkov, S.; Müller, F. Mapping ecosystem service supply, demand and budgets. Ecol. Indic. 2012, 21, 17-29. [CrossRef]

19. Teoh, S.H.S.; Symes, W.S.; Sun, H.; Pienkowski, T.; Carrasco, L.R. A global meta-analysis of the economic values of provisioning and cultural ecosystem services. Sci. Total Environ. 2019, 649, 1293-1298. [CrossRef]

20. Stürck, J.; Poortinga, A.; Verburg, P.H. Mapping ecosystem services: The supply and demand of flood regulation services in Europe. Ecol. Indic. 2014, 38, 198-211. [CrossRef]

21. Zhao, W.; Liu, Y.; Daryanto, S.; Fu, B.; Wang, S.; Liu, Y. Metacoupling supply and demand for soil conservation service. Curr. Opin. Environ. Sustan. 2018, 33, 136-141. [CrossRef]

22. Goldenberg, R.; Kalantari, Z.; Cvetkovic, V.; Mörtberg, U.; Deal, B.; Destouni, G. Distinction, quantification and mapping of potential and realized supply-demand of flow-dependent ecosystem services. Sci. Total Environ. 2017, 593-594, 599-609. [CrossRef]

23. Larondelle, N.; Lauf, S. Balancing demand and supply of multiple urban ecosystem services on different spatial scales. Ecosyst. Serv. 2016, 22, 18-31. [CrossRef]

24. Zhai, T.L.; Wang, J.; Jin, Z.F.; Qi, Y. Change and correlation analysis of the supply-demand pattern of ecosystem services in the Yangtze River Economic Belt. Acta Ecol. Sin. 2019, 39, 5414-5424. (In Chinese)

25. Shi, Y.; Shi, D. Study on the balance of ecological service supply and demand in Dongting Lake Ecological Economic Zone. Geogr. Res. 2018, 37, 1717-1723. (In Chinese)

26. Blanco, V.; Holzhauer, S.; Brown, C.; Lagergren, F.; Vulturius, G.; Lindeskog, M.; Rounsevell, M.D.A. The effect of forest owner decision-making, climatic change and societal demands on land-use change and ecosystem service provision in Sweden. Ecosyst. Serv. 2017, 23, 174-208. [CrossRef]

27. Bryan, B.A.; Ye, Y.; Zhang, J.'e.; Connor, J.D. Land-use change impacts on ecosystem services value: Incorporating the scarcity effects of supply and demand dynamics. Ecosyst. Serv. 2018, 32, 144-157. [CrossRef]

28. Brunner, S.H.; Huber, R.; Grêt-Regamey, A. A backcasting approach for matching regional ecosystem services supply and demand. Environ. Model. Softw. 2016, 75, 439-458. [CrossRef]

29. Aziz, T. Changes in land use and ecosystem services values in Pakistan, 1950-2050. Environ. Dev. 2021, 37, 100576. [CrossRef]

30. Inácio, M.; Karnauskaitè, D.; Baltranaitè, E.; Kalinauskas, M.; Bogdzevič, K.; Gomes, E.; Pereira, P. Ecosystem services of the Baltic Sea: An assessment and mapping perspective. Geogr. Sustain. 2020, 1, 256-265.

31. Srichaichana, J.; Trisurat, Y.; Ongsomwang, S. Land Use and Land Cover Scenarios for Optimum Water Yield and Sediment Retention Ecosystem Services in Klong U-Tapao Watershed, Songkhla, Thailand. Sustainability 2019, 11, 2895. [CrossRef]

32. Wei, F.; Zhan, X. Delineating Urban Growth Boundaries with Ecosystem Service Evaluation. Sustainability 2019, 11, 5390. [CrossRef]

33. Chaplin-Kramer, R.; Sharp, R.P.; Weil, C.; Bennett, E.M.; Pascual, U.; Arkema, K.K.; Brauman, K.A.; Bryant, B.P.; Guerry, A.D.; Haddad, N.M. Global modeling of nature's contributions to people. Science 2019, 366, 255-258. [CrossRef]

34. Wang, J.; Zhai, T.; Lin, Y.; Kong, X.; He, T. Spatial imbalance and changes in supply and demand of ecosystem services in China. Sci. Total Environ. 2019, 657, 781-791. [CrossRef] [PubMed]

35. Peng, J.; Yang, Y.; Xie, P.; Liu, Y. Zoning for the construction of green space ecological networks in Guangdong Province based on the supply and demand of ecosystem services. Acta. Ecol. Sin. 2017, 37, 4562-4572. (In Chinese)

36. Xie, G.D.; Lu, C.X.; Leng, Y.F.; Zheng, D.; Li, S.C. Ecological assets valuation of the Tibetan Plateau. J. Nat. Resour. 2003, 18, 189-196. (In Chinese)

37. Lu, C.X.; Xie, G.D.; Xiao, Y.; Yu, Y.J. Ecosystem diversity and economic valuation of Qinghai-Tibet Plateau. Acta. Ecol. Sin. 2004, 24, 2749-2755. (In Chinese)

38. Jiang, W.; Lü, Y.; Liu, Y.; Gao, W. Ecosystem service value of the Qinghai-Tibet Plateau significantly increased during 25 years. Ecosyst. Serv. 2020, 44, 101146. [CrossRef]

39. Zheng, D.; Zhao, D. Characteristics of natural environment of the Tibetan Plateau. Sci. Technol. Rev. 2017, 35, 13-22. (In Chinese)

40. Immerzeel, W.; Stoorvogel, J.; Antle, J. Can payments for ecosystem services secure the water tower of Tibet? Agric. Syst. 2008, 96, 52-63. [CrossRef]

41. Barnett, T.P.; Adam, J.C.; Lettenmaier, D.P. Potential impacts of a warming climate on water availability in snow-dominated regions. Nature 2005, 438, 303-309. [CrossRef] [PubMed]

42. Zhou, L.; Dang, X.; Sun, Q.; Wang, S. Multi-scenario simulation of urban land change in Shanghai by random forest and CA-Markov model. Sustain. Cities Soc. 2020, 55, 102045. [CrossRef]

43. Zhou, L.; Dang, X.; Mu, H.; Wang, B.; Wang, S. Cities are going uphill: Slope gradient analysis of urban expansion and its driving factors in China. Sci. Total Environ. 2021, 775, 145836. [CrossRef] [PubMed]

44. Zhou, Y.; Zhang, X.; Yu, H.; Liu, Q.; Xu, L. Land Use-Driven Changes in Ecosystem Service Values and Simulation of Future Scenarios: A Case Study of the Qinghai-Tibet Plateau. Sustainability 2021, 13, 4079. [CrossRef] 